ペットボトルおよび午入り緑茶飲料の加温保存中における 各種カテキン類および抗酸化能の変化

\author{
独立行政法人 農業・生物系特定産業技術研究機構 野菜茶業研究所* \\ 木幡勝則・峰伸一・氏原ともみ・堀江秀樹** \\ (平成15年 7 月 31 日受理)
}

\title{
Changes in Catechin Contents and Anti-oxidative Activities during the Hot Storage of PET Bottole and Canned Green Tea Beverages
}

\author{
Katsunori Kohata, Shinichi Mine, Tomomi Ujihara, Hideki Horie \\ National Institute of Vegetable and Tea Science \\ National Agricultural and Bio-oriented Research Organization
}

\begin{abstract}
Summary
Changes in catechin contents and anti-oxidative activities during the hot storage $\left(55^{\circ} \mathrm{C}\right)$ of PET (polyethylene terephthalate) bottle and canned green tea beverages were investigated by HPLC and the discoloration of $\beta$-carotene coupled with the oxidation of linolic acid $(\beta$ carotene anti-oxidative activity) and the scavenging activity of DPPH (1,1-Diphenyl-2picrylhydrazyl) radical, respectively. Furthermore, relationship between the anti-oxidative activities and the contents of tea components were also investigated. The $\beta$-carotene antioxidative activity in both beverages and the scavenging activity of DPPH in canned beverage hardly changed, nevertheless the scavenging activity of DPPH in PET bottle beverage tended to decrease slightly (about 10\%) during the hot storage. Ester typed catechins ( $\mathrm{EGCg}+\mathrm{ECg}+$ $\mathrm{GCg}+\mathrm{Cg}$ ) decreased about $14 \%$, on the other hand free typed catechins (EC $+\mathrm{EGC}+\mathrm{GC}+$ C) decreased about 10\%. Ascorbic acid (VC) decreased about $12 \%$ in the PET bottle beverage, but hardly changed in the canned beverage. It is assumed from the changes of catechins and VC that the canned beverage is sealed more airtightly than the PET bottle one. It is said that self lives of PET bottle and canned beverages are 2 weeks. This storage length is reasonable for the shelf life in view of the changes in the catechin contents and anti-oxidative activities.
\end{abstract}

Key Words : PET bottle and canned green tea, anti-oxidative activity, hot storage, quality evaluation

* $\overline{\mathbf{T}} 428-8501$ 静岡県榛原郡金谷町金谷2769

** 現 =514-2392 三重県安芸郡安濃町大字草生 360 
ペットボトルおよび缶入り緑茶飲料の加温保存中における各種カテキン類および抗酸化能の変化

\section{1. 緒言}

$500 \mathrm{ml} 350 \mathrm{ml}$ といった小型のペットボトル 入り緑茶飲料 (ペットボトル飲料) や缶入り 緑茶飲料（缶飲料）は，消費者の健康志向や 新商品の相次ぐ販売により近年消費が急増し ている。それを背景に，力テキン類等の成分 がどの程度に含まれているのか，また，抗酸 化能はどの程度なのかを明らかにしたいとい う観点から，成分分析および抗酸化能測定が 試みられ，一部報文化もされている し, 保存中における抗酸化能変化について, また, 成分含有量と抗酸化能変化との相関に ついてはこれまでに報告された例は見当た らない。

特に，最近は消費者ニーズの多様化を反映 して, 加温専用のペットボトル飲料も市販さ れており，加温保存中の成分含有量やそれに 伴う抗酸化能変化がどの程度なのかを知りた いという要望が一段と高まってきている。

そこで, 本論文では, 成分として主要力テ キン類 4 種とそのエピ体 4 種の計 8 種のカテ キン類とアスコルビン酸 (VC) を, 抗酸化能 として $\beta$-カロテン退色法による抗酸化能 (以 下， $\beta$-カロテン抗酸化能と略す) と DPPH (1,1-Diphenyl-2-picrylhydrazyl) ラジカル 捕捉能を取り上げ，加温保存 $\left(55^{\circ} \mathrm{C}\right)$ 中に扔け る各種カテキン類および抗酸化能の変化つい て検討したので報告する。併せて, 抗酸化能 の変化と成分含有量との相関について検討し たので報告する。

なお,本論文で得られた結果は,市販のペッ トボトルおよび缶飲料において得られたもの である。

\section{2. 実 験 方 法}

\section{1 ペットボトル扔よび罀飲料}

ペットボトル飲料は市販の $300 \mathrm{ml}$ 入りホッ 卜専用 (原材料は緑茶, 香料の使用なし) を, 缶飲料は市販の $350 \mathrm{ml}$ 入 (原材料は緑茶, 香 料の使用なし）をそれぞれ用いた。両飲料と も同じロットのものを購入して用いた。恒温 糟中 $55^{\circ} \mathrm{C}$ で保存し，1，2，3および 5 週間
後に抗酸化能および個別カテキン類とVC含 有量を測定した。測定は 3 連で行った。

\section{2 . $2 \beta$-カロテン抗酸化能およびDPPH ラジカル捕捉能の測定}

測定は前報に従った4)。ただし，試料液は ペットボトルおよび缶飲料ともに 7 倍希釈し たものを用いた。

\section{3 カテキン類およびVC含有量の測定} 文献 に従い, 主要カテキン類 4 種 $(\mathrm{EC}$, $\mathrm{EGC}, \mathrm{EGCg}, \mathrm{ECg})$ とそのエピ体 4 種 (C, GC, $\mathrm{GCg}, \mathrm{Cg})$ の計 8 種およびVCを同時定量し た。ペットボトルおよび缶飲料ともに 2 倍希 釉して試料液とした。

\section{4 統計処理 \\ チューキーの多重比較により行った。}

\section{3．実験結果と考察}

3. 1 ペットボトル飲料

加熱保存中に抢ける $\beta$-カロテン抗酸化能 の変化を表 1 に示した。一週間後の保存にお ける值が少し増加していたが，全体的には開 始時の值と比較して, わずかに減少するに留 まった。 5 週間加温保存中における $\beta$-カロテ ン抗酸化能の変化（減少）は，わずかである といえる。

一方, DPPHラジカル補足能は, 保存が長 くなるに従い減少する傾向にあったが，減少 は最大で $10 \%$ 程度であり，それ程大きくはな かった（図 1 )。

カテキン類含有量の変化を表 2 に示した。 個別力テキン類 8 種とも保存中に減少する傾 向にあり, 主要カテキン類 8 種の合計量では 5 週間後には約 $14 \%$ 減少していた。減少の内 訳を見てみると, 遊離型カテキン類 $(\mathrm{C}+$ $\mathrm{GC}+\mathrm{EC}+\mathrm{EGC}$ ，遊離型と略す）の減少が約 $9 \%$ あったのに対し，エステル型カテキン 類 $(\mathrm{Cg}+\mathrm{GCg}+\mathrm{ECg}+\mathrm{EGCg}$, エステル型と略 す）では約 $19 \%$ と遊離型のほほ 2 倍であり， 後者の方がより変化しやすいことが示唆され 


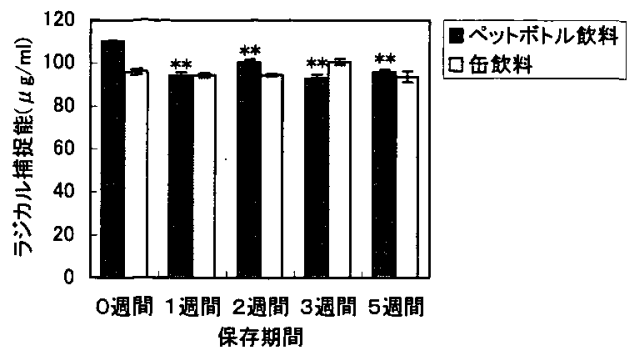

図 1 ペットボトルおよび缶入り緑茶飲料の加 温保存中におけるDPPH捕捉能の变化

捕捉能は6-Hydroxy-2, 5, 7,8-tetramethylchroman-2-carboxylicacid(Trolox) 濃 度 $(\mu \mathrm{mol})$ 相当量として表した。チュー キ一の多重比較において，0 週間の值を基 に, “は $5 \%$ で, **は $1 \%$ で有意差のあるも のを示す。

た。しかし，エステル型が一部加水分解して 遊離型に変化したために後者の減少が少な かったことも考えられる。また，VC添加溶液 中で行われた既存の報告 ${ }^{6}$ によると，必ずし もエステル型が遊離型よりも变化しやすいと いう結果ではなく，エステル型が遊離型より も変化しやすいかどうかに関しては今後の検 討が待たれる。ただし，今回の測定では，エ ステル型が分解して遊離型になる際に生成す るはずの没食子酸の増加が認められなかった ことから，エステル型の遊離型への分解はな かったか, あってもわずかであったと推察さ れる。

カテキン類の変化を，さらに，個別に見て
みると, $\mathrm{ECg} \geqq \mathrm{GCg}>\mathrm{Cg}>\mathrm{EGCg}>\mathrm{EC}>\mathrm{C}>$ $\mathrm{GC}>\mathrm{EGC}$ 順に変化しやすいことが示唆さ れた。これらの結果は，これまでに緑茶浸出 液中における個別カテキン含有量の変化に関 する報告にはなく,初めての知見といえるが， 上述したようにカテキン類の分解に関して は, 今後の詳細な検討が待たれる。

その他, 通常の緑茶浸出液と比較したペッ トボトル飲料の特徴として, (1)主要カテキン 類 4 種とそのエピ体 4 種のそれぞれの含有量 がほほ等しいこと，(2)遊離型がエステル型の 約1.8倍多く含まれていること，(3)EGCとGC 含有量が最も多く, 次に多いEGCgと $\mathrm{GCg}$ の 約 2 倍多く含まれていること等が挙げられ る。これらの特徵はこれまでの報告 ${ }^{1)}$ と概ね 一致するものの, 含有量比は必ずしも一致し ていなかった。含有量比は温度, 時間等の浸 出液の調製条件によって変化することを考慮 すれば，当然の結果といえる。

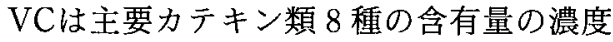
比で約 $60 \%$ 含まれていた。通常の緑茶浸出液 には, 主要カテキン類 4 種の約 $7 \%$ 程度しか 含まれていないことから，酸化防止剤として 添加されたものであることがよくわかる。VC は保存中に減少する傾向にあり，5週間後に は約 $12 \%$ 減少した（表 2 ）。

成分含有量と $\beta$-カ口テン抗酸化能との相 関に関して, $\beta$-カロテン抗酸化能は保存期間 中大きな変化が見られなかったことから, 有 効なデータは得られなかった。

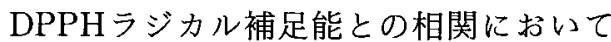

表 1 ペットボトルおよび缶入り緑茶飲料の $\beta$ ーカロテン抗酸化能

\begin{tabular}{ccc}
\hline 加温保存期間 & \multicolumn{2}{c}{ 抗酸化能 $(\%) \pm$ 標準偏差 a ) } \\
& ペットボトル & 缶 \\
\hline 0 週間 & $74.79 \pm 0.64$ & $59.41 \pm 5.84$ \\
1 週間 & $84.66 \pm 6.80$ & $55.77 \pm 2.34$ \\
2 週間 & $74.15 \pm 3.59$ & $68.29 \pm 1.44$ \\
3 週間 & $69.47 \pm 3.55$ & $60.73 \pm 4.83$ \\
5 週間 & $69.16 \pm 3.54$ & $54.17 \pm 1.66$ \\
\hline
\end{tabular}

a) (試料溶液 0 分後の吸光度 -30 分後の吸光度 $) \times 100$

(BHA ( $1 \mathrm{mg} / 100 \mathrm{ml}) 0$ 分後の吸光度 -30 分後の吸光度)

0 週間の值を基に,チューキーの多重比較を行ったが，いずれも有意差は認められなかった。 
は，VCおよびエステル型にVC含有量を加え た値とに弱いながら正の相関が認められた

(図2)。主要カテキン類 8 種にVCを加えた 含有量との間にもエステル型ほどではないも のの，弱い正の相関のあることが認められた $\left(\mathrm{R}^{2}=0.6291\right)$ 。ペットボトル飲料中のVC含 有量の多さが反映されたものと推察される。

前報の「熟度別抗酸化能の変化」に関する 検討)では，抗酸化能の変化はDPPHラジカ ル捕捉能よりも $\beta$-カロテン抗酸化能により 反映されることを明らかにしたが，本論文で は相反する結果であった。カテキン類とVCの 濃度比や遊離型とエステル型カテキン類の存 在比の違い等の原因が考元られるが，この原 因については今後検討する必要がある。

\section{2 缶飲料}

加温保存中に抢ける $\beta$-カロテン抗酸化能 の変化を表 1 に示した。 5 週間の加温保存中
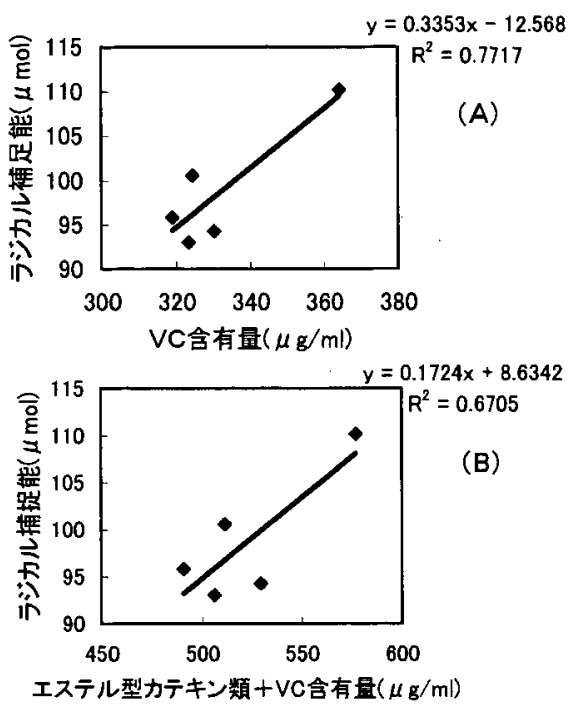

図 2 ペットポトル入り緑茶飲料における成分含有 量とDPPH補足能との相関

(A) VC含有量との相関

(B) エステル型カテキン類+VC含有量との相関

\section{表 2 ペットボトル入り緑茶飲料における加温保存中の成分含有量变化}

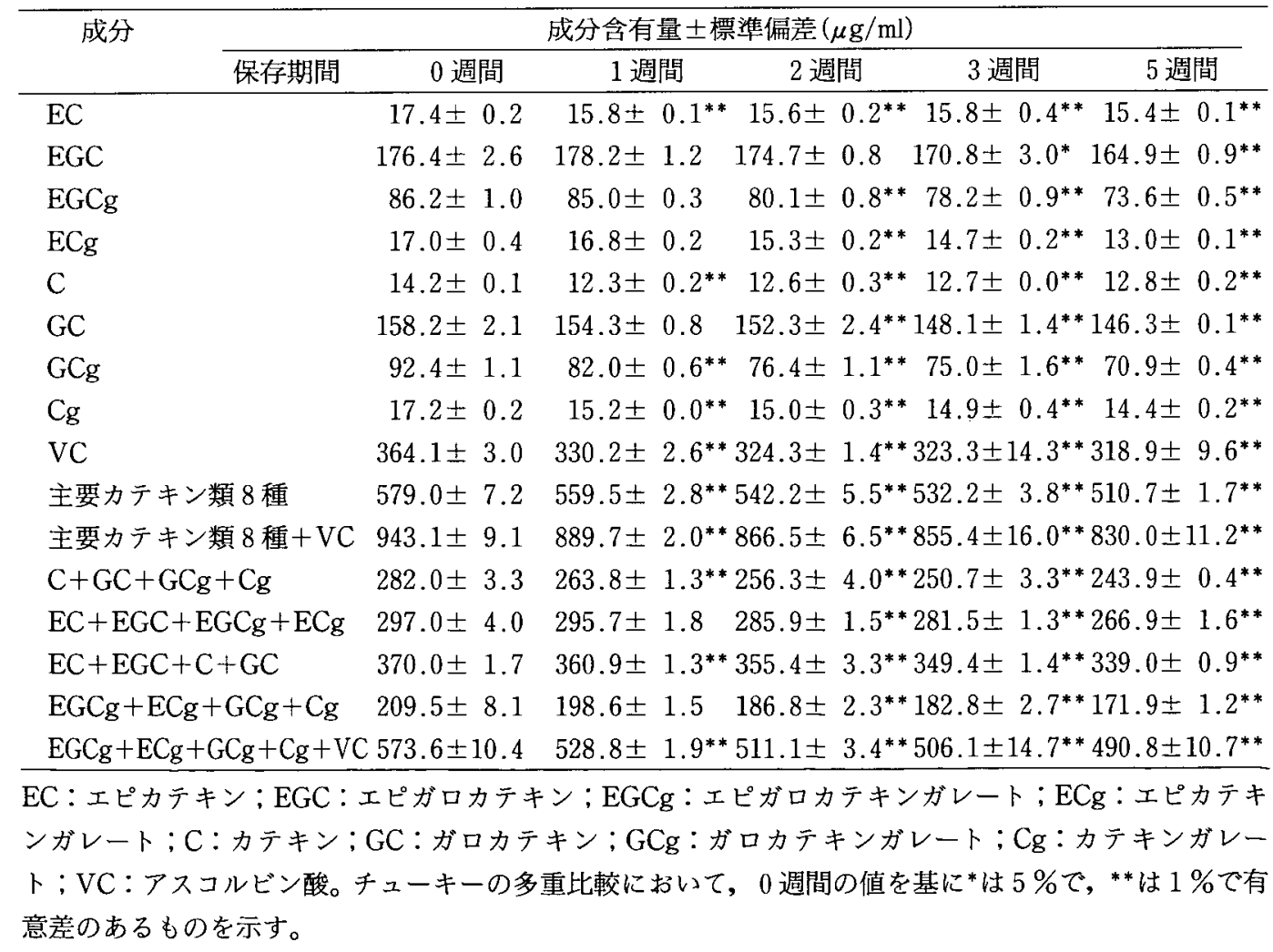


には大きく変化しておらず，従って，ペット ボトル飲料と同様に変化はほとんどなかった ものと結論した。

DPPHラジカル補足能も保存中はほとん ど変化がなかった（図 1 )。

カテキン類含有量の変化を表 3 に示した。 個別カテキン類 8 種とも保存中に減少する傾 向にあり，合計した主要カテキン類 8 種では 5 週間後には約 $10 \%$ 減少した。減少の内訳を 見てみると, 遊離型 $(\mathrm{C}+\mathrm{GC}+\mathrm{EC}+\mathrm{EGC})$ の 減少が約 $7 \%$ であったのに対し，エステル型 $(\mathrm{CGg}+\mathrm{GCg}+\mathrm{ECg}+\mathrm{EGCg})$ では約 $14 \%$ と 遊離型力テキン類のほほ 2 倍であり, 後者の 方がより変化しやすいことが示唆された。 ペットボトル飲料とほほ同様の傾向にあった が，減少率は缶飲料の方が少なかった。これ は, ペットボトルと比較して缶の方が容器の 気㨸性が高いことに起因しているものと考察 される。
カテキン類の減少を個別に見てみると, $\mathrm{ECg}>\mathrm{GCg}>\mathrm{Cg}>\mathrm{GC}>\mathrm{EGCg}>\mathrm{EC}>\mathrm{C}>$ EGCの順に減少率の大きいことがわかった。 ペットボトル飲料の結果と比較して,GCの減 少割合が大きかった以外は，同じ順序であっ たことから，この結果はペットボトルおよび 缶飲料中のカテキン類変化の特徴といえる。 その他のペットボトル飲料の特徴として上述 した，(1)主要カテキン類 4 種とそのエピ体 4 種の含有量がほほ等しいこと，(2)遊離型がエ ステル型の約1.6倍多く含まれていること,(3) $\mathrm{EGC}$ とGC含有量が最も多く, 次いで多い EGCgとGCgの約 2 倍多く含まれていたこと も午飲料に共通した特徴であった。

VCはペットボトル飲料と同樣に, 主要カテ キン類 8 種の含有量の約 $60 \%$ 含まれていた が，ペットボトル飲料の結果と異なって，保 存中はほとんど変化しなかった (表 2)。カテ キン類の変化の項でも述べたように，ペット

\section{表 3 缶入り緑茶飲料における加温保存中の成分含有量変化}

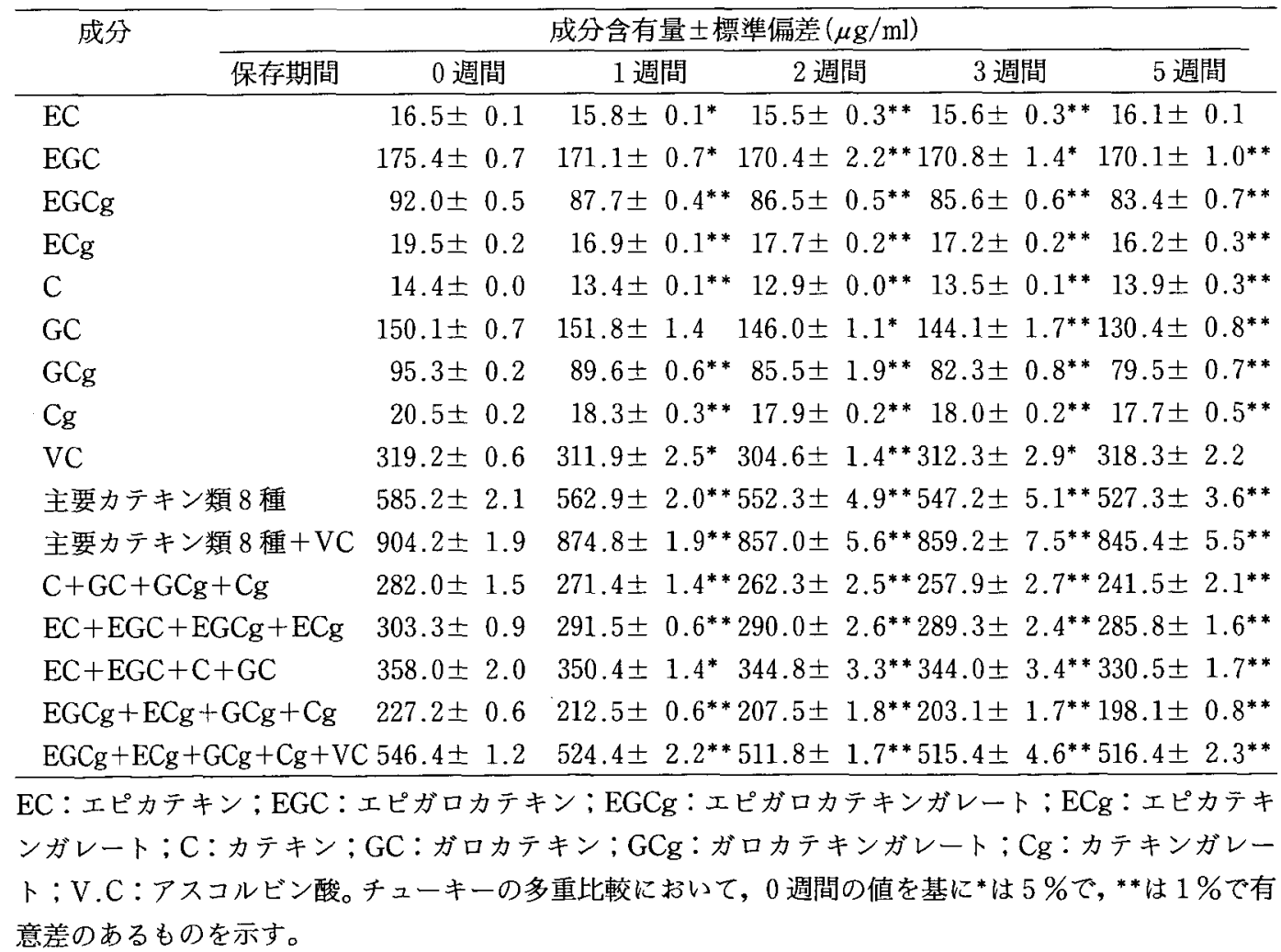


ボトルと比較して缶の方が容器の気密性が高 いことに起因しているものと推察される。

$\beta$-カロテン抗酸化能, DPPHラジカル補足 能共にカテキン類及びVC含有量との間には相 関が認められなかった(データ未記載)。双方 の抗酸化能とも保存中ほとんど変化しなかっ たことを考慮すれば，当然の結果といえる。

本論文で得られたペットボトルおよび䭌飲 料の抗酸化能の值を, 市販煎茶を標準的な条 件で淹れたときのそれと比較すると，おおよ そ 4 〜 6 割程度であった。この比較は同じ量 を飲んだと仮定したときのもので，もし，前 茶は 1 杯 $(100 \mathrm{ml})$,ペットボトルおよび午飲料 は 1 本 $(350 \mathrm{ml})$ 飲んだと仮定すると,ペットボ トルおよび缶飲料の方が1.5〜2 倍強い抗酸 化能が期待できることになる。

一方，加温保存した場合のペットボトルお よび缶飲料の賞味期限は 2 週間とされてい る。本論文で得られた保存 2 週間目の結果か らも抗酸化能および成分含有量変化は小さい ことが示された。色や香りにおいてはわずか に変化することが認められるものの, 飲料と して問題になる程ではないことから，2 週間 という賞味期限は妥当といえる。一方で, 缶 よりペットボトル飲料の方が成分変化が大き いことが明らかとなった。これは, 気密性に おいて缶の方が優れており，空気による茶成 分の酸化がより抑えられるためと推察される。

\section{4. 摘要}

ペットボトルおよび䇶飲料の加温保存 $\left(55^{\circ} \mathrm{C}\right.$ で最大 5 週問) 中の抗酸化能および成分含有量 変化について, 以下の点が明らかとなった。

(1) $\beta$-カロテン抗酸化能は両飲料においてもほと んど変化しなかった。DPPHラジカル捕捉能 は,ペットボトル飲料においてはやや減少す る傾向にあったが, 缶飲料ではほとんど変化 しなかった。抗酸化能と成分含有量との相関 では, ペットボトル飲料において，VCおよ びエステル型あるいは主要カテキン類 8 種に
VCを加えた値とに弱いながら正の相関か認 められた。

(2) 主要カテキン類 8 種の含有量はペットボトル 飲料で約 $14 \%$, 缶飲料で約 $10 \%$ 減少した。双 方において,エステル型が遊離型の約 2 倍隇 少割合が大きく,より変化しやすいことが推 察された。VCはペットボトル飲料では約 $12 \%$ 減少したが,缶飲料ではほとんど変化しなか力 た。ペットボトル飲料において成分変化が大 きかったのは, 午飲料と比較して容器の気密 性が劣る点に起因しているものと推察される。

(3) 保存 2 週間目の抗酸化能および成分含有量 の変化が小さかったことから, 賞味期限 2 週 間という期間は妥当であることが示された。

\section{5. 引用 文 献}

1）小林千種 - 中里光男 - 山嶋裕希子・川合由 華・立石恭也・安田和男 (1998)：茶葉及び 茶飲料中のカテキン類, メチルキサンチン 類及びアスコルビン酸の分析, 東京衛研年 報，49,135-143.

2 ）小林千種 - 中里光男 - 山嶋裕希子・川合由 華・立石恭也・安田和男 (1999)：茶抽出物 を添加した食品中のカテキン類及びメチル キサンチン類の分析, 東京衛研年報, 50,101-106.

3 ) 暒本五郎・村上智嘉子 (1999): 各種市販茶 の抗酸化性とそれらの成分，日本栄養・食 糧学会誌, $52,209-218$.

4 ) 木幡勝則・峰伸一・氏原ともみ・堀江秀樹 (2003) : 茶葉の熟度別抗酸化能の変化, 茶 研報, №.96, 投稿中.

5 ) 堀江秀樹・山本(前田)万里・氏原ともみ・ 木幡勝則(2003) : 茶葉中力テキン類分析の ための抽出方法の検討, 茶研報, №.94, 60-64.

6) Chen,Z-Y., Q. Y. Zhu, Y. F. Wong, Z. Zhang and H. Y. Chung (1998):

Stabilizing effect of ascorbic acid on green tea catechins, J. Agric. Food Chem., 46, 2512-2516. 